\title{
Incorporation and Portrayal of Cultures in Pedagogic Discourse in Pakistan: A Study of Teachers' Perspectives
}

\author{
AZHAR HABIB \\ National University of Modern Languages, \\ Islambad, Pakistan \\ MUHAMMAD YOUSAF \\ National University of Modern Languages, \\ Islambad, Pakistan \\ usaf_pak@yahoo.com \\ FARZANA MASROOR \\ Air University, \\ Islamabad, Pakistan \\ IJAZ ALI KHAN \\ Government Post Graduate College, \\ Sawabi, Pakistan
}

\begin{abstract}
Teachers' views regarding the portrayal of cultures in English textbooks they teach are of paramount importance. Nevertheless, there is a lack of research studies on this area worldwide, and more specifically, in Pakistani contexts. The present study aimed to get the views of English teachers regarding the incorporation and portrayal of various cultures in the reading passages of English textbooks used for teaching at secondary level in the government schools of Sindh. The study is purely quantitative whereby a questionnaire was developed using the framework of Cortazzi and Jin (2013) to get the opinions of teachers on ten cultural variables of source, target and international target cultures. Each variable has two parts - the first was to gain information about a particular variable in the textbooks; the second was to know about its representation. The data were analysed using SPSS. Moreover, a t-test was also applied to determine whether the findings are statistically valid. The study's findings show that the prescribed textbooks provide sufficient and realistic information about different cultural variables of source culture(s). In contrast, the textbooks do not provide sufficient and realistic information about different cultural variables of international culture (s) except that the textbooks realistically depict men and women. As to target culture(s), the textbooks provide sufficient and realistic information about some of the variables: history, interaction patterns of people with one another, social identities/classes, customs and traditions, and equal representation of both men and women. However, the textbooks do not provide sufficient and realistic information about some of the variables. These include geography, social/political institutions, religions, art and artefacts, and the everyday life of the people. In view of the results, it is suggested that a balanced approach should be adopted regarding the incorporation and portrayal of various cultures in the textbooks. The research is significant as it provides guidelines to policymakers, textbooks writers and researchers by underlining the importance of incorporating varied cultures in academic discourse.
\end{abstract}

Keywords: cultures; teachers; English; textbooks

\section{INTRODUCTION}

The incorporation of various cultures has become very vital in present-day language teaching. The present study is a modest attempt to get teachers' views on the incorporation and representation of various cultures in the reading passages of the English textbooks they teach at the secondary level in the government schools of Sindh, a province of Pakistan. There are several reasons for the need to focus on cultural aspects in academic discourse. One of its grounds is the extensive mobility of the population worldwide, resulting in widespread contacts and interactions among groups with varied languages and cultures (Habib, 2020). For this 
reason, the purpose of learning a foreign language is no longer merely for the acquisition of communicative competence. It is now a requisite for teachers to teach intercultural communicative competence (Sercu, 2005).

In educational institutions, teachers and teaching materials/textbooks play an essential role in enhancing the multifarious skills of the students. Teachers are the mediators between students and teaching materials. Therefore, it is essential to get their views about the materials they use. This is also endorsed by Davcheva and Sercu (2005). According to them, learning materials and textbooks play an important role in the teaching of foreign languages; hence, it is useful to research into the ways in which teachers perceive the value of teaching materials and textbooks for developing intercultural learning. In the same way, teachers are considered the messengers of language and culture by Iriskulova (2012). As such, researchers in the field underline the importance of teachers' perspectives on the teaching materials in use and the subject matter they convey.

The researchers of the present study also considered teachers' feedback on language textbooks valuable as their views would help to improve the quality of textbooks. Habib (2014) highlights the importance of textbooks in the context of Pakistan as both teachers and students rely heavily on textbooks due to the unavailability of other materials and resources in Pakistan. Keeping in view the important role that textbooks play in Pakistani contexts, the present study seeks to obtain the views of teachers regarding the integration and portrayal of various cultures in their use of English textbooks at the secondary school level.

\section{LITERATURE REVIEW}

According to Longman Dictionary of Language Teaching and Applied Linguistics (2010, p.151), culture is "the set of practices, codes and values that mark a particular nation or group: the sum of a nation or group's most highly thought of works of literature, art, music, etc.". Herron et al. (2000) classified culture into big "C" culture, and little "c"; big "C" culture consists of literary works, music and art. On the other hand, little "c" culture includes everyday life, customs, beliefs, values, and behaviour.

As far as language teaching is concerned, language and culture are closely connected. Jiang (2000) has illustrated the close connection between the two from a philosophical perspective. He posits that language and culture are akin to a living organism whereby language and culture constitute flesh and blood, symbolically. Thus, language, i.e. the flesh, would die without the presence of culture, i.e. the blood and likewise, culture would be shapeless without language. To conclude, it can be said that language cannot be learnt without learning the culture of the people who speak it.

Textbooks are an essential source for learning different skills of a particular language and the culture(s) of the people who speak the language. The mobility of population worldwide for different purposes and the excessive use of English language both by native and non-native speakers alike have made it compulsory to acquire not only communicative competence (Hymes, 1972) but also other competencies in which the role of culture(s) is crucial. Examples of other competencies include intercultural communicative competence, meta cultural competence (Sharifian, 2013), multidialectal competence (Canagarajah, 2006), global cultural consciousness (Kumaravadivelu, 2008) and intercultural citizenship (Byram 2011). As textbooks are the only source for learning in many situations globally, they should have appropriate content for enhancing learners' various competencies.

Cortazzi and Jin (2013) have classified materials related to cultures into three main categories: source, target and international target cultures. Each has its advantages, and too much emphasis on any one of them has disadvantages too. Source culture refers to the culture(s) 
of people learning a second or foreign language. In the case of Pakistani English learners, it is the culture(s) of Pakistan. Alptekin (1993, p.141) posited that known cultural schemas help learners to acquire foreign language skills, particularly comprehension.

Instead of diving simplistically into the narrow confines of a given target language culture, in a manner devoid of comparative insight and critical perspective, EFL writers should try to build conceptual bridges between the culturally familiar and the unfamiliar in order not to give rise to conflicts in the learner's 'fit' as he or she acquires English (p.141).

In terms of the portrayal of learners' culture(s), when textbooks are written or compiled by local writers, they focus on the culture of learners. This has also been highlighted by Iriskulova (2012). For constructing national/Muslim identities, local cultures also get the attention of writers. The results of the studies conducted by Habib and Saleem (2016) in Pakistan and Aliakbari (2004) in Iran also attest to it.

Target culture means the culture(s) of those whose language learners are learning, in the English language, the culture(s) of the people of inner-circle countries, i.e. England, America, Australia, etc. Politzer (1959) stresses the importance of target culture and posits that "if we teach language without teaching at the same time the culture in which it operates, we are teaching meaningless symbols or symbols to which student attaches the wrong meaning" (p.100-101). Nault (2006) underlines the incorporation of learners' culture(s) and international culture(s) in teaching materials. However, he argues that it does not mean to ignore the cultures of England and America in language teaching as students' understanding would be incomplete without the knowledge of these important cultures.

International target culture refers to the culture(s) of people who are learning and using the target language, or English, for international communication, e.g. in Singapore and Japan. Wandel (2003, p.73) has talked about two main changes that are unavoidable due to the dimension of culture in education if we deem English a world language. Firstly, the cultural and geographical range of English as a foreign language (EFL) teaching must be extended by including cultures of other English speaking countries besides the USA and UK. As such, countries such as Nigeria, South Africa, Canada, India, Australia and their cultures must be considered, and they "will start playing an increasingly more relevant role in the EFLclassroom". Secondly, to develop students' intercultural sensitivity, they should know various cultural perspectives, outlooks and tools for analysing fundamental facets of the cultures. To instill cultural awareness in the learners, Nault (2006) has also emphasised integrating world cultures in EFL teaching.

Several studies have been conducted regarding textbooks in Pakistan to assess whether they are helpful as tools to develop communicative competence in learners (Ashraf, 2008; Aftab 2011; Umar, 2013; Iqbal, 2013; Habib, 2014a; Mohibullah, 2021). Among these studies, a few of them investigated textbooks in terms of the presence of cultural elements in the content. Mahmood et al. (2012) studied Step Ahead 1 taught in some elite schools of Pakistan at grade 6 using content analysis by adopting Byram and Morgan's (1994) framework. It was found that the textbook has references to Singaporean culture only, and the culture of learners and target cultures are not covered. Yaqoob (2011) investigated textbooks used for teaching in government and elite schools at the secondary level to find the ideologies hidden in them and their effect on learners using Fairclough's (2003) framework of CDA. He found that the textbooks used in government and elite schools promote different ideologies. Cobussen (2008) investigated the textbook used in Punjab, one of the provinces of Pakistan, in terms of its cultural contents and the type or variety of language used in it and found that the cultural elements are related to Pakistani and, more specifically, to Punjabi culture.

Habib (2014b) conducted a study on the textbooks of Khyber Pakhtunkhwa, a province of Pakistan used at the secondary level to examine the representation of various cultures using 
content analysis and checklist of Byram and Morgan (1994) and found that a balanced approach has not been followed for the portrayal of cultures. Ahmed and Narcy-Combes (2011) investigated textbooks written by foreign writers and used in private schools to assess how cultures of learners are delineated using a questionnaire and an adapted checklist. They found that the portrayal of learners' culture was not up to the mark as the writers were not well aware of the cultures of learners. Dar and Masroor (2019), who investigated the textbooks used for teaching grade 5 students to determine how they disseminate various cultures using content analysis and Fairclough's (2003) model, found that provincial ideologies are embedded in some of the textbooks. The studies in the context of Pakistan indicate that few studies have been conducted on textbooks to assess their cultural content. Moreover, there is no comprehensive research to probe into teachers' views regarding cultural aspects in the textbooks that they use. The present study is an attempt to fill this research gap.

\section{METHODOLOGY}

The study was purely quantitative, and the specific method adopted was descriptive and in the form of a survey research. A questionnaire for English teachers was made; its validity and reliability were calculated and administered to 68 English teachers ( 37 male and 31 female) who were teaching the prescribed textbooks to students of grades 9 and 10 (age range of students was between 14 and16). The students of government schools in Sindh study two English textbooks at the secondary level. Secondary Stage English Book One is used to teach students of grade 9. It is prepared and approved by the Sindh Textbook Board, Jamshoro. It consists of twenty-one units. Secondary Stage English Book Two is taught to students of grade 10. It is also prepared and approved by the Sindh Textbook Board, Jamshoro. The textbook has twenty-six units. The validity of the questionnaire was checked using content validity. Content validity refers to "the degree to which a test/instrument measures an intended content area" (Gay, n.d., p. 155). It has two types: item and sampling validity that determine whether items are pertinent and cover the whole area. It does not need any statistics, and it requires an expert in the field to go through the items and provide suggestions. For the present study, two PhD. Holders in Applied Linguistics evaluated the questionnaire and provided suggestions that were then incorporated by the researchers. For the reliability of the instrument, Cronbach Alpha was used. Its value was 0.9 , which means that it was reliable. The questionnaire was adapted from the framework of Cortazzi and Jin (2013). They emphasise materials related to the source, target and international target cultures in textbooks. Ten cultural variables were put in the questionnaire regarding the source, target and international target cultures. They are history, geography, social identities/classes, equal representation of men and women, social and political institutions, customs and traditions, art and artefacts, interaction patterns, religion, and everyday life. These variables were considered keeping in view the following checklists:

Chastain (1988)

Byram \& Morgan (1994)

Tomalin and Stempleski (1993)

CEFR (Council of Europe, 2001)

Each cultural variable has two parts; the first is to know about the cultural information regarding a specific variable in the textbooks, the second is to know whether the cultural information is realistically represented. In this way, there were twenty items of three cultures, and the total number of items was sixty. For analysis, SPSS was employed for providing percentages, mean and standard deviation. Moreover, inferential statistics, t-test was applied to 
ascertain that the results were statistically significant. The p-value of all the responses was 0.00 .

\section{THEORETICAL FRAMEWORK}

The study is based on the Intercultural Language Learning (IcLL) theory as purported by Liddicoat et al. (2003). IcLL underscores "the fusing of language, culture and learning into a single educative approach" (p.43). The objectives of IcLL are: to understand and value all languages and cultures (languages and cultures of learners as well as of target communities); to understand and value how to mediate among languages and cultures; and to develop intercultural sensitivity as a continuing goal in learners. The ultimate goal of IcLL is to enhance Intercultural Communicative Competence (ICC) in learners. For achieving and analysing the objectives of Intercultural Language Learning, several checklists have been devised. Notable checklists are Chastain (1988), Tomalin and Stempleski (1993), Byram (1993), Cortazzi and Jin (2013), and CEFR (Council of Europe, 2001) etc.

\section{DATA ANALYSIS}

The responses of English teachers on the source, target and international target cultures are given below:

TABLE 1. Teachers' responses about source culture(s) in the textbooks

\begin{tabular}{|c|c|c|c|c|c|c|c|c|c|}
\hline $\begin{array}{l}\text { S. } \\
\#\end{array}$ & Statement & SD & $\mathrm{DA}$ & $\mathrm{U}$ & A & SA & $\mathrm{T} \%$ & $\mathrm{M}$ & $\mathrm{SD}$ \\
\hline 1 & $\begin{array}{l}\text { provide information about the history of } \\
\text { SC(s) }\end{array}$ & 22.1 & 2.9 & 8.8 & 41.2 & 25 & 100 & 3.44 & 1.47 \\
\hline 2 & $\begin{array}{l}\text { give a realistic representation of the } \\
\text { history of } \mathrm{SC}(\mathrm{s})\end{array}$ & 2.9 & 5.9 & 16.2 & 29.4 & 45.6 & 100 & 4.08 & 0.06 \\
\hline 3 & $\begin{array}{l}\text { provide information about the } \\
\text { geography of SC(s) }\end{array}$ & 23.5 & 16.2 & 8.8 & 26.5 & 25 & 100 & 3.13 & 1.54 \\
\hline 4 & $\begin{array}{l}\text { give a realistic representation of the } \\
\text { geography of SC(s) }\end{array}$ & 22.1 & 10.3 & 10.3 & 27.9 & 29.4 & 100 & 3.32 & 1.53 \\
\hline 5 & $\begin{array}{l}\text { provide knowledge about social } \\
\text { identities/classes of } \mathrm{SC}(\mathrm{s})\end{array}$ & 11.8 & 5.9 & 2.9 & 50 & 29.4 & 100 & 3.79 & 1.26 \\
\hline 6 & $\begin{array}{l}\text { give a realistic representation of the } \\
\text { social identities/classes of } \operatorname{SC}(\mathrm{s})\end{array}$ & 26.5 & 1.5 & 2.9 & 20.6 & 48.5 & 100 & 3.63 & 1.69 \\
\hline 7 & $\begin{array}{l}\text { provide equal representation of both } \\
\text { men and women with reference to } \mathrm{SC}(\mathrm{s})\end{array}$ & 17.6 & 0 & 2.9 & 45.6 & 33.8 & 100 & 3.77 & 1.39 \\
\hline 8 & $\begin{array}{l}\text { give a realistic representation of both } \\
\text { men and women with reference to } \mathrm{SC}(\mathrm{s})\end{array}$ & 8.8 & 1.5 & 0 & 39.7 & 50 & 100 & 4.20 & 1.15 \\
\hline 9 & $\begin{array}{l}\text { provide information about the socio- } \\
\text { political institutions of SC(s) }\end{array}$ & 10.3 & 0 & 20.6 & 33.8 & 35.3 & 100 & 3.83 & 1.21 \\
\hline 10 & $\begin{array}{l}\text { give a realistic representation of the } \\
\text { socio-political institutions of } \operatorname{SC}(s)\end{array}$ & 11.8 & 1.5 & 20.6 & 29.4 & 36.8 & 100 & 3.77 & 1.29 \\
\hline 11 & $\begin{array}{l}\text { give equal coverage to different } \\
\text { religions of the SC(s) }\end{array}$ & 7.4 & 16.2 & 2.9 & 32.4 & 41.2 & 100 & 3.83 & 1.32 \\
\hline 12 & $\begin{array}{l}\text { give a realistic representation of } \\
\text { different religions of the } \mathrm{SC}(\mathrm{s})\end{array}$ & 4.4 & 13.2 & 4.4 & 38.2 & 39.7 & 100 & 3.95 & 1.17 \\
\hline
\end{tabular}




\begin{tabular}{|c|c|c|c|c|c|c|c|c|c|}
\hline 13 & $\begin{array}{l}\text { provide information about the } \\
\text { interaction patterns of people with one } \\
\text { another with reference to SC(s) }\end{array}$ & 1.5 & 8.8 & 32.4 & 20.6 & 36.8 & 100 & 3.82 & 1.07 \\
\hline 14 & $\begin{array}{l}\text { give a realistic representation of the } \\
\text { interaction patterns of people with one } \\
\text { another with reference to SC(s) }\end{array}$ & 14.7 & 2.9 & 29.4 & 23.5 & 29.4 & 100 & 3.5 & 1.34 \\
\hline 15 & $\begin{array}{l}\text { provide knowledge about the customs } \\
\text { and traditions of } \mathrm{SC}(\mathrm{s})\end{array}$ & 14.7 & 1.5 & 7.4 & 30.9 & 45.6 & 100 & 3.91 & 1.39 \\
\hline 16 & $\begin{array}{l}\text { give a realistic representation of the } \\
\text { customs and traditions of } \mathrm{SC}(\mathrm{s})\end{array}$ & 17.6 & 2.9 & 5.9 & 26.5 & 47.1 & 100 & 3.82 & 1.49 \\
\hline 17 & $\begin{array}{l}\text { provide knowledge about the art and } \\
\text { artifacts of } \mathrm{SC}(\mathrm{s})\end{array}$ & 20.6 & 11.8 & 11.8 & 20.6 & 35.3 & 100 & 3.38 & 1.56 \\
\hline 18 & $\begin{array}{l}\text { give a realistic representation of the art } \\
\text { and artifacts of } \mathrm{SC}(\mathrm{s})\end{array}$ & 7.4 & 17.6 & 13.2 & 32.4 & 29.4 & 100 & 3.58 & 1.28 \\
\hline 19 & $\begin{array}{l}\text { provide knowledge about everyday life } \\
\text { of people of SC(s) }\end{array}$ & 13.2 & 8.8 & 13.2 & 33.8 & 30.9 & 100 & 3.60 & 1.36 \\
\hline 20 & $\begin{array}{l}\text { give a realistic representation of } \\
\text { everyday life of people of } \mathrm{SC}(\mathrm{s})\end{array}$ & 13.2 & 10.3 & 14.7 & 36.8 & 25 & 100 & 3.50 & 1.33 \\
\hline
\end{tabular}

Table 1 shows the responses of English teachers about different cultural elements of source culture(s). The first two items of the questionnaire were about information related to history, its presence and representation. The results show that more than $65 \%$ of the teachers believe that the textbooks provide information about the history of source culture(s). Likewise, $75 \%$ of the teachers opined that the information about history is realistically represented. Hence, the results show that the history of the source culture gets adequate attention. Items 3 and 4 were about the geography of source culture(s). The results reveal that more than $50 \%$ of the teachers agreed that the textbooks provide information about geography.

Similarly, about $60 \%$ opined that the history of source culture(s) is represented realistically. Thus, the results show that the geography of the source cultures is sufficiently portrayed in the textbooks. Items 5 and 6 were about social identities/classes of source culture(s). The results demonstrate that about $80 \%$ of the teachers agreed that the information about social identities and classes are provided in the prescribed textbooks. In the same way, $80 \%$ of the teachers opined that social identities and classes are realistically portrayed. Hence, the results show that social identities and classes of the source culture get adequate attention.

Items 7 and 8 were about the equal and realistic representation of both men and women of source culture(s). The findings reveal that about $80 \%$ of the teachers opine that the textbooks give equal coverage to both men and women. Likewise, $90 \%$ of the teachers respond that both genders are realistically depicted in the textbooks. It means that men and women of source cultures get the attention of the textbooks writers. Items 9 and 10 of the questionnaire were about the coverage and representation of socio-political institutions of source culture(s). The results indicate that $70 \%$ of the teachers agreed that the prescribed textbooks provide information on socio-political institutions.

In the same way, about $65 \%$ of the teachers opined that the information about sociopolitical institutions is realistically portrayed. Thus, the results indicate that socio-political institutions of source culture(s) are adequately represented in the textbooks. Items 11 and 12 of the questionnaire were included to ascertain coverage and realistic representation of different religions of the source culture(s). The findings show that more than $70 \%$ of the teachers responded that the textbooks give coverage to different religions. Likewise, about $80 \%$ opined that cthe overage of different religions related to source culture(s) is realistic. It shows that religions are sufficiently portrayed in the textbooks. Statements 13 and 14 are about the information and realistic representation of the interaction patterns of people of the source 
culture(s). The results indicate that more than $50 \%$ of the teachers opined that the prescribed textbooks provide information regarding people of the source culture(s) and that such information is realistically portrayed.

Statements 15 and 16 were about the information and realistic portrayal of customs and traditions of source culture(s) in the textbooks. The results show that $75 \%$ of the teachers believed that the prescribed textbooks provide information about customs and traditions of source culture(s). Similarly, $70 \%$ of the teachers opined that the information about customs and traditions is realistically depicted. Thus, most of the teachers believe that customs and traditions of source culture(s) are adequately portrayed. Items 17 and 18 were about information and realistic representation of the art and artefacts of source culture(s). The findings indicate that $55 \%$ of the teachers responded that the information related to art and artefacts is provided in the textbooks.

In the same way, $60 \%$ of the teachers opined that the information related to art and artefacts is realistically portrayed in the textbooks. Statements 19 and 20 were put to get teachers' opinion about information and realistic representation of everyday life of people of source culture(s). The results demonstrate that $60 \%$ of the teachers opined that the prescribed textbooks provide information related to the everyday life of people of source culture(s). Moreover, they also posited that the information is realistically depicted.

TABLE 2. Teachers' responses about target culture(s) in the textbooks

\begin{tabular}{|c|c|c|c|c|c|c|c|c|c|}
\hline $\begin{array}{l}\text { S. } \\
\#\end{array}$ & Statement & SD & DA & $\mathrm{U}$ & $\mathrm{A}$ & SA & $\mathrm{T} \%$ & $\mathrm{M}$ & SD \\
\hline 1 & $\begin{array}{l}\text { provide information about the history of } \\
\text { TC(s) }\end{array}$ & 11.8 & 0 & 7.4 & 44.1 & 36.8 & 100 & 3.94 & 1.23 \\
\hline 2 & $\begin{array}{l}\text { give a realistic representation of the history } \\
\text { of } \mathrm{TC}(\mathrm{s})\end{array}$ & 11.8 & 29.4 & 2.9 & 35.3 & 20.6 & 100 & 3.23 & 1.38 \\
\hline 3 & $\begin{array}{l}\text { provide information about the geography } \\
\text { of TC(s) }\end{array}$ & 0 & 35.3 & 23.5 & 30.9 & 10.3 & 100 & 3.16 & 1.03 \\
\hline 4 & $\begin{array}{l}\text { give a realistic representation of the } \\
\text { geography of TC(s) }\end{array}$ & 19.1 & 30.9 & 20.6 & 25 & 4.4 & 100 & 2.64 & 1.18 \\
\hline 5 & $\begin{array}{l}\text { provide knowledge about social } \\
\text { identities/classes of TC(s) }\end{array}$ & 2.9 & 27.9 & 13.2 & 41.2 & 14.7 & 100 & 3.36 & 1.13 \\
\hline 6 & $\begin{array}{l}\text { give a realistic representation of the social } \\
\text { identities/classes of TC(s) }\end{array}$ & 11.8 & 14.7 & 11.8 & 55.9 & 5.9 & 100 & 3.29 & 1.15 \\
\hline 7 & $\begin{array}{l}\text { provide equal representation of both men } \\
\text { and women with reference to TC(s) }\end{array}$ & 8.8 & 1.5 & 14.7 & 55.9 & 19.1 & 100 & 3.75 & 1.07 \\
\hline 8 & $\begin{array}{l}\text { give a realistic representation of both men } \\
\text { and women with reference to } \mathrm{TC}(\mathrm{s})\end{array}$ & 1.5 & 5.9 & 11.8 & 64.7 & 16.2 & 100 & 3.88 & 0.80 \\
\hline 9 & $\begin{array}{l}\text { provide information about the socio- } \\
\text { political institutions of TC(s) }\end{array}$ & 1.5 & 5.9 & 45.6 & 38.2 & 8.8 & 100 & 3.47 & 0.80 \\
\hline 10 & $\begin{array}{l}\text { give a realistic representation of the socio- } \\
\text { political institutions of } \mathrm{TC}(\mathrm{s})\end{array}$ & 0 & 10.3 & 42.6 & 44.1 & 2.9 & 100 & 3.39 & 0.71 \\
\hline 11 & $\begin{array}{l}\text { give equal coverage to different religions } \\
\text { of the TC(s) }\end{array}$ & 1.5 & 29.4 & 23.5 & 35.3 & 10.3 & 100 & 3.23 & 1.03 \\
\hline 12 & $\begin{array}{l}\text { give a realistic representation of different } \\
\text { religions of the TC(s) }\end{array}$ & 8.8 & 17.6 & 27.9 & 29.4 & 16.2 & 100 & 3.26 & 1.19 \\
\hline 13 & $\begin{array}{l}\text { provide information about the interaction } \\
\text { patterns of people with one another with } \\
\text { reference to TC(s) }\end{array}$ & 1.5 & 8.8 & 36.8 & 47.1 & 5.9 & 100 & 3.47 & 0.80 \\
\hline
\end{tabular}




\begin{tabular}{|c|c|c|c|c|c|c|c|c|c|}
\hline 14 & $\begin{array}{l}\text { give a realistic representation of the } \\
\text { interaction patterns of people with one } \\
\text { another with reference to TC(s) }\end{array}$ & 4.4 & 20.6 & 32.4 & 32.4 & 10.3 & 100 & 3.23 & 1.03 \\
\hline 15 & $\begin{array}{l}\text { provide knowledge about the customs and } \\
\text { traditions of TC(s) }\end{array}$ & 1.5 & 23.5 & 11.8 & 47.1 & 16.2 & 100 & 3.52 & 1.07 \\
\hline 16 & $\begin{array}{l}\text { give a realistic representation of the } \\
\text { customs and traditions of } \mathrm{TC}(\mathrm{s})\end{array}$ & 2.9 & 29.4 & 16.2 & 38.2 & 13.2 & 100 & 3.29 & 1.12 \\
\hline 17 & $\begin{array}{l}\text { provide knowledge about the art and } \\
\text { artifacts of TC(s) }\end{array}$ & 23.5 & 20.6 & 14.7 & 30.9 & 10.3 & 100 & 2.83 & 1.36 \\
\hline 18 & $\begin{array}{l}\text { give a realistic representation of the art } \\
\text { and artifacts of TC(s) }\end{array}$ & 8.8 & 30.9 & 16.2 & 39.7 & 4.4 & 100 & 3.0 & 1.11 \\
\hline 19 & $\begin{array}{l}\text { provide knowledge about everyday life of } \\
\text { people of TC(s) }\end{array}$ & 5.9 & 33.8 & 23.5 & 32.4 & 4.4 & 100 & 2.95 & 1.04 \\
\hline 20 & $\begin{array}{l}\text { give a realistic representation of everyday } \\
\text { life of people of TC(s) }\end{array}$ & 4.4 & 27.9 & 38.2 & 22.1 & 7.4 & 100 & 3.0 & 0.99 \\
\hline
\end{tabular}

Table 2 shows the responses of English teachers to different cultural elements of the target culture(s). The first two items of the questionnaire were about information related to history, its presence and representation. The results show that $80 \%$ of the teachers believe that the textbooks provide information about the history of target cultures. Likewise, $55 \%$ of the teachers opined that the information about history is realistically represented. To conclude, the textbooks provide sufficient and reliable information about history. Items 3 and 4 were about the geography of the target culture(s). The results reveal that only $40 \%$ of the teachers agreed that the textbooks provide information about geography.

Similarly, only $29 \%$ of teachers opined that the history of the target culture(s) is represented realistically. To conclude, the textbooks do not provide sufficient information about geography. Items 5 and 6 were about social identities/classes of the target culture(s). The results demonstrate that $55 \%$ of the teachers agreed that information about social identities and classes are provided in the prescribed textbooks. In the same way, more than $60 \%$ of the teachers opined that information about social identities/classes is realistically portrayed. It means that the textbooks provide sufficient information about social identities and classes.

Items 7 and 8 were about the equal and realistic representation of both men and women of the target culture(s). The findings reveal that $75 \%$ of the teachers were of the view that the textbooks give equal coverage to both men and women. Likewise, $80 \%$ of the teachers responded that both genders are realistically depicted in the textbooks. To conclude, textbook writers paid equal attention to men and women of target cultures. Items 9 and 10 of the questionnaire were about coverage and representation of socio-political institutions of the target culture(s). The results indicate that more than $50 \%$ of the teachers were either uncertain about it or disagreed with the statement that the prescribed textbooks provide information regarding socio-political institutions.

In the same way, more than $50 \%$ of the teachers were uncertain, and they disagreed that information about socio-political institutions is realistically portrayed. Items 11 and 12 of the questionnaire were about the coverage and realistic representation of different religions of the target culture(s). The findings show that more than $50 \%$ of the teachers were either uncertain about it or disagreed that textbooks give coverage to different religions. Likewise, more than $50 \%$ of the teachers were either uncertain or disagreed that the coverage of different religions of the target culture(s) is realistic.

Statements 13 and 14 were about the information and realistic representation of the interaction patterns of people of the target culture(s). The results indicate that more than $50 \%$ of the teachers opined that the prescribed textbooks provide information regarding interaction patterns of people of the target culture(s). However, only $43 \%$ of the teachers felt that such 
information is realistically provided. Statements 15 and 16 were about information related to customs and traditions of the target culture(s) and its realistic representation in the textbooks. The results show that $63 \%$ of the teachers believed that the prescribed textbooks provide information about customs and traditions of the target culture(s).

Similarly, $51 \%$ of the teachers expressed their view that the information on customs and traditions is realistically depicted. Items 17 and 18 were about the information and realistic representation of the target culture's art and artefacts (s). The findings indicate that more than $50 \%$ of the teachers were either uncertain about it or disagreed with the statement that information related to art and artefacts is provided in the textbooks. Similarly, only $44 \%$ of the teachers opined that the art and artefacts are realistically portrayed in the textbooks. Statements 19 and 20 were put to get teachers' opinions about information and realistic representation of the everyday lives of people of the target culture(s). The results demonstrate that about $65 \%$ of the teachers disagreed with the statement that the prescribed textbooks provide information about the everyday lives of people of the target culture(s). Moreover, 70\%were either uncertain or disagreed that the information is realistically depicted.

TABLE 3. Teachers' responses about international target cultures in the textbooks

\begin{tabular}{|c|c|c|c|c|c|c|c|c|c|}
\hline $\begin{array}{l}\text { S. } \\
\text { \# }\end{array}$ & Statement & SD & DA & $\mathrm{U}$ & A & $\mathrm{SA}$ & $\begin{array}{l}\mathrm{T} \\
\%\end{array}$ & $\mathrm{M}$ & SD \\
\hline 1 & $\begin{array}{l}\text { provide information about the history of } \\
\text { ITC(s) }\end{array}$ & 1.5 & 14.7 & 48.5 & 26.5 & 8.8 & 100 & 3.26 & 0.87 \\
\hline 2 & $\begin{array}{l}\text { give a realistic representation of the history of } \\
\text { ITC(s) }\end{array}$ & 14.7 & 13.2 & 33.8 & 25.0 & 13.2 & 100 & 3.08 & 1.23 \\
\hline 3 & $\begin{array}{l}\text { provide information about the geography of } \\
\text { ITC(s) }\end{array}$ & 22.1 & 32.4 & 16.2 & 25 & 4.4 & 100 & 2.57 & 1.21 \\
\hline 4 & $\begin{array}{l}\text { give a realistic representation of the geography } \\
\text { of ITC(s) }\end{array}$ & 17.6 & 39.7 & 26.5 & 11.8 & 4.4 & 100 & 2.45 & 1.05 \\
\hline 5 & $\begin{array}{l}\text { provide knowledge about social } \\
\text { identities/classes of ITC(s) }\end{array}$ & 23.5 & 16.2 & 26.5 & 30.9 & 2.9 & 100 & 2.73 & 1.21 \\
\hline 6 & $\begin{array}{l}\text { give a realistic representation of the social } \\
\text { identities/classes of ITC(s) }\end{array}$ & 25 & 20.6 & 32.4 & 22.1 & 0 & 100 & 2.51 & 1.09 \\
\hline 7 & $\begin{array}{l}\text { provide equal representation of both men and } \\
\text { women with reference to ITC(s) }\end{array}$ & 11.8 & 19.1 & 20.6 & 45.6 & 2.9 & 100 & 3.08 & 1.11 \\
\hline 8 & $\begin{array}{l}\text { give a realistic representation of both men and } \\
\text { women with reference to ITC(s) }\end{array}$ & 11.8 & 10.30 & 8.8 & 61.8 & 7.4 & 100 & 3.42 & 1.15 \\
\hline 9 & $\begin{array}{l}\text { provide information about the socio-political } \\
\text { institutions of ITC(s) }\end{array}$ & 19.1 & 16.2 & 23.5 & 39.7 & 1.5 & 100 & 2.88 & 1.17 \\
\hline 10 & $\begin{array}{l}\text { give a realistic representation of the socio- } \\
\text { political institutions of ITC(s) }\end{array}$ & 19.1 & 22.1 & 20.6 & 36.8 & 1.5 & 100 & 2.79 & 1.17 \\
\hline 11 & $\begin{array}{l}\text { give equal coverage to different religions of } \\
\text { the ITC(s) }\end{array}$ & 17.6 & 36.8 & 10.3 & 26.5 & 8.8 & 100 & 2.72 & 1.27 \\
\hline 12 & $\begin{array}{l}\text { give a realistic representation of different } \\
\text { religions of the ITC(s) }\end{array}$ & 25 & 29.4 & 11.8 & 22.1 & 11.8 & 100 & 2.66 & 1.37 \\
\hline 13 & $\begin{array}{l}\text { provide information about the interaction } \\
\text { patterns of people with one another with } \\
\text { reference to ITC(s) }\end{array}$ & 5.9 & 23.5 & 22.1 & 33.8 & 14.7 & 100 & 3.27 & 1.15 \\
\hline
\end{tabular}




\begin{tabular}{|c|c|c|c|c|c|c|c|c|c|}
\hline 14 & $\begin{array}{l}\text { give a realistic representation of the interaction } \\
\text { patterns of people with one another with } \\
\text { reference to ITC(s) }\end{array}$ & 19.1 & 11.8 & 42.6 & 26.5 & 0 & 100 & 2.76 & 1.05 \\
\hline 15 & $\begin{array}{l}\text { provide knowledge about the customs and } \\
\text { traditions of ITC(s) }\end{array}$ & 13.2 & 33.8 & 17.6 & 33.8 & 1.5 & 100 & 2.76 & 1.10 \\
\hline 16 & $\begin{array}{l}\text { give a realistic representation of the customs } \\
\text { and traditions of ITC(s) }\end{array}$ & 22.1 & 27.9 & 16.2 & 26.5 & 7.4 & 100 & 2.69 & 1.28 \\
\hline 17 & $\begin{array}{l}\text { provide knowledge about the art and artefacts } \\
\text { of ITC(s) }\end{array}$ & 36.8 & 22.1 & 2.9 & 17.6 & 20.6 & 100 & 2.63 & 1.61 \\
\hline 18 & $\begin{array}{l}\text { give a realistic representation of the art and } \\
\text { artefacts of ITC(s) }\end{array}$ & 17.6 & 26.5 & 23.5 & 23.5 & 8.8 & 100 & 2.79 & 1.24 \\
\hline 19 & $\begin{array}{l}\text { provide knowledge about the everyday life of } \\
\text { people of ITC(s) }\end{array}$ & 16.2 & 36.8 & 27.9 & 11.8 & 7.4 & 100 & 2.57 & 1.12 \\
\hline 20 & $\begin{array}{l}\text { give a realistic representation of everyday life } \\
\text { of people of ITC(s) }\end{array}$ & 14.7 & 33.8 & 26.5 & 25 & 0 & 100 & 2.61 & 1.02 \\
\hline
\end{tabular}

Table 3 shows the responses of English teachers regarding different cultural elements of the international target culture(s). The first two items of the questionnaire were about information related to history, its presence and representation. The results show that $48.5 \%$ of the teachers were uncertain that the textbooks provide information about the history of the international target culture(s). Moreover, $16 \%$ of the teachers disagreed with the statement. It means that the textbooks do not provide information about history. Likewise, $33.8 \%$ of the teachers were uncertain, and $28 \%$ disagreed that the information about history is realistically represented. It means that the textbooks do not depict the history of the international target culture(s) realistically. Item 3 and 4 were about the geography of the international target culture(s). The results reveal that more than $52 \%$ of the teachers disagreed with the statement that the textbooks provide information about geography. Besides, $16 \%$ were uncertain about it. Thus, it means that the textbooks do not provide information about geography.

Similarly, $57 \%$ opined that the history of the international target culture(s) is not represented realistically. Moreover, $26.5 \%$ of teachers are uncertain about its realistic representation. It means that the textbooks do not portray geography realistically. Items 5 and 6 were about social identities and classes of the international target culture(s). The results demonstrate that $39.7 \%$ of the teachers disagreed with the statement that information about social identities and classes are provided in the prescribed textbooks. Besides, $26.5 \%$ of teachers were uncertain about such information. To conclude, the textbooks do not provide information about social identities and classes.

In the same way, $45.6 \%$ of the teachers responded that information about social identities/classes is not realistically portrayed. Furthermore, $32.4 \%$ of teachers were uncertain about the realistic representation of social identities and classes. The results show that the textbooks do not portray social identities and classes of the international target culture(s) realistically.

Items 7 and 8 were about the equal and realistic representation of both men and women of the international target culture(s). The findings reveal that about $48.5 \%$ of the teachers opined that the textbooks give equal coverage to both men and women, while the remaining disagreed or were uncertain about it. It means the textbooks do not give equal coverage to men and women. Likewise, $69.2 \%$ of the teachers responded that both genders are realistically depicted in the textbooks, while the remaining were either uncertain or disagreed with the statement. It means that the textbooks realistically portray both men and women. Items 9 and 10 of the questionnaire were about coverage and representation of socio-political institutions of the international target culture(s). The results indicate that $41.2 \%$ of the teachers agreed that 
the prescribed textbooks provide information regarding socio-political institutions, while the remaining teachers were either uncertain or disagreed with the statement.

To sum up, the textbooks do not provide information about socio-political institutions. In the same way, about $38.3 \%$ of the teachers opined that the information about socio-political institutions is realistically portrayed, while the remaining were either uncertain about it or disagreed with the statement. To conclude, socio-political institutions are not realistically portrayed. Items 11 and 12 of the questionnaire were about the coverage and realistic representation of different religions of the international culture(s). The findings show that $35.5 \%$ of the teachers responded that the textbooks give coverage to different religions, whereas the remaining were either uncertain or disagreed with the statement. It means that the textbooks do not give coverage to religions. Likewise, about $33.9 \%$ of teachers opined that coverage of different religions of international target culture(s) is realistic, whereas the remaining teachers were either uncertain about it or disagreed with the statement.

To sum up, the textbooks do not realistically portray different religions. Statements 13 and 14 were about the information and realistic representation of people's interaction patterns of the international target culture(s). The results indicate that more than $48.5 \%$ of the teachers opined that the prescribed textbooks provide information regarding interaction patterns of people of the international target culture(s). However, $29.4 \%$ disagreed with the statement, and $22.10 \%$ were uncertain. To conclude, the textbooks do not provide sufficient information about the interaction patterns of people. Likewise, $26.5 \%$ of teachers opined that information regarding interaction patterns of people of the international target culture(s) is realistic, whereas $30.90 \%$ disagreed with the statement. However, $42.6 \%$ of teachers were either uncertain whether or not information regarding people's interaction patterns of the international target culture(s)is realistically portrayed.s To sum up, the textbooks do not provide sufficient information about the interaction patterns of people. Moreover, the information they provide are not realistically portrayed.

Statements 15 and 16 aimed to gather information related to customs and traditions of international culture(s) and their realistic representation. The results show that $35.3 \%$ of the teachers believed that the prescribed textbooks provide information about the customs and traditions of the international target culture(s). Nevertheless, $47 \%$ of teachers disagreed with the statement. Moreover, $17.6 \%$ of teachers were uncertain about the statement. To conclude, the textbooks do not provide sufficient information about the customs and traditions of international target cultures. Similarly, $33.9 \%$ of the teachers opined that the information on customs and traditions is realistically depicted, whereas $50 \%$ of the teachers viewed that they do not provide information regarding them realistically. Furthermore, $16.2 \%$ were uncertain about the statement. To sum up, the textbooks do not provide such information realistically. Items 17 and 18 were about the information and realistic representation of the art and artefacts of the international target culture(s). The findings indicate that $38.2 \%$ of the teachers responded that information related to art and artefacts is provided in the textbooks. In contrast, $58.9 \%$ of teachers were against this view. Moreover, $2.9 \%$ of teachers were uncertain about the provision of such information. To conclude, the textbooks do not provide information related to art and artefacts of the international target culture(s). Similarly, $32.3 \%$ of the teachers opined that information related to art and artefacts is realistically portrayed in the textbooks, whereas $44.1 \%$ disagreed with the statement. Furthermore, $23.5 \%$ of teachers were uncertain about it.

To sum up, the textbooks do not give a realistic representation of the art and artefacts of the international target culture(s). Statements 19 and 20 were put to get teachers' opinions about information and realistic representation of people's everyday lives of the international target culture(s). The results demonstrate that $19.2 \%$ of the teachers felt that the prescribed textbooks provide information related to people's everyday lives of the international target culture(s). On the other hand, 53\% of teachers disagreed with the statement. Moreover, $27.9 \%$ 
of teachers were uncertain about the provision of such information. To conclude, the textbooks do not provide sufficient information about the everyday life of the people of the international target culture(s). In the same way, $25 \%$ of teachers posited that the textbooks give a realistic representation of the everyday life of the people of the international target culture(s). In contrast, $48.5 \%$ of teachers thought that textbooks do not give a realistic representation of people's everyday lives. Moreover, $26.5 \%$ of teachers were uncertain about it. To conclude, the textbooks do not give a realistic representation of the people of the international target culture(s).

\section{FINDINGS OF THE STUDY}

\section{SOURCE CULTURE(S)}

In terms of the different cultural variables of source culture(s), most of the teachers were of the opinion that the prescribed textbooks provide sufficient information about source culture(s). Furthermore, they opined that the textbooks give a realistic portrayal of source culture(s). The highest mean value, i.e. 4.2 is of item 8 . In this regard, $89.7 \%$ of teachers opined that the textbooks give a realistic representation of both men and women of the source culture(s). The lowest mean value, i.e. 2.45 , is of item 3 . It is shown that $51.5 \%$ of teachers opined that the prescribed textbooks provide information about the geography of source culture(s). The remaining teachers were either uncertain, or they believed that the textbooks do not provide information about geography.

\section{TARGET CULTURE(S)}

In terms of teachers' responses about different cultural variables of the target culture(s), they agreed with 9 statements and disagreed with 11 statements of the questionnaire. They opined that the textbook provides information about history, interaction patterns of people with one another, social identities/classes, customs and traditions of target culture(s), and equal representation to both men and women of the target culture(s). Besides, their view was that the textbooks give a realistic representation of history, social identities/classes, customs and traditions, and men and women of the target culture(s). On the other hand, they pointed out that the prescribed textbooks do not provide sufficient information about geography, social and political institutions, religions, art and artefacts, and everyday life of the people of the target culture(s). Furthermore, their views show that the prescribed textbooks do not give a realistic representation of geography, social and political institutions, religions, art and artefacts, interaction patterns of people with one another, and everyday life of the people of the target culture(s).

\section{INTERNATIONAL TARGET CULTURE(S)}

Concerning the cultural variables of the international target culture(s), the view of most teachers was that the prescribed textbooks do not provide sufficient information about international target culture(s). Likewise, most teachers believe that the textbooks do not provide a realistic portrayal of the international target culture(s). Nevertheless, only one variable had a favourable opinion; $69.2 \%$ of the teachers were of the opinion that the textbooks give a realistic representation of both men and women of the international target culture(s). The mean value for the item is 3.42. Item No. 4 has the lowest mean value, i.e. 2.45. It is about the realistic representation of the geography of the international target culture(s). In this regard, only $16.2 \%$ of teachers opined that the textbooks give a realistic representation of the 
geography of the international target culture(s). In contrast, the remaining teachers were either uncertain or believed that the textbooks do not give a realistic representation of the geography of the international target culture(s).

\section{DISCUSSION AND CONCLUSION}

The study aimed to know about teachers' views regarding incorporating and portraying various cultures in English textbooks. The findings of the study reveal that the textbooks provide sufficient information about all the cultural variables of source culture(s). Moreover, they give a realistic representation of all the cultural variables of source culture(s). Hence, the textbooks provide learners with the opportunities of understanding and valuing their own culture, as is propounded in the theory of Intercultural Language Learning (IcLL). Iriskulova (2012) has posited that when textbooks are prepared locally, the writers highlight the culture(s) of the learners. One reason for emphasising local cultures is to construct national and Muslim identities (Aliakbari, 2004; Habib \& Saleem, 2016). Thus, the results of the present study are in line with the views of Iriskulova and the findings of Aliakbari and Habib and Saleem, who researched Iran and Pakistan, respectively.

Regarding target culture(s), the textbooks provide practical information about cultural elements like history, interaction patterns of people with one another, social identities/classes, customs, and traditions. They give equal representation to both men and women of the target culture(s). However, they do not provide practical information about some cultural variables such as geography, social and political institutions, religions, art and artefacts, interaction patterns of people with one another, and everyday life of the people of the target culture(s). It means that the textbooks provide reliable information about five cultural aspects, and the remaining five are backgrounded. In view of the status of English as an international language, it is argued that elements of world cultures and source cultures in teachings materials need to be included. For example, Nault (2006) underscored the incorporation of source and international cultures in the textbooks.

Nevertheless, he posited that cultural elements of the cultures of the UK and USA should not be sifted out from teaching materials as learners' learning experience would be incomplete if they did not know these important cultures. The theory of Intercultural Language Learning (IcLL) also advocates providing opportunities to learners "to understand and value one's target language(s) and culture(s)" (p. 43). However, the study's findings show that the prescribed textbooks do not provide sufficient information to achieve the goals of Intercultural Language Learning.

The textbooks do not provide enough information about the cultural variables of the international target culture(s). Besides, they do not give a realistic representation of cultural variables of international culture(s) except one, i.e. the textbooks give a realistic representation of both men and women of the international target culture(s). Several researchers have advocated incorporating materials related to world cultures/international target cultures keeping in view the status of English as an international language (Wandel, 2003; Nault, 2006). Nault (2006) advised educators to integrate world cultures in the teaching contents for the promotion of "true linguistic/cultural awareness and international understanding among themselves and their students" (p. 325). Thus from the perspective of the teachers concerned, the textbooks do not provide sufficient information about international target cultures. 


\section{IMPLICATIONS OF THE STUDY}

The study's findings indicate that the teachers concerned are not satisfied with the cultural load and portrayal of varied cultures in the textbooks they teach. It has three broad implications. First, the prescribed textbooks need considerable improvement from the perspective of cultural aspects. Second, the teachers who teach English textbooks ought to be consulted while writing or compiling textbooks. Lastly, in such cases where cultures are not covered in a balanced way in the textbooks, the relevant teachers should cater to students' needs by providing supplementary materials to learners regarding the areas where they think the textbooks are deficient. Moreover, relevant research in the area indicates the scarcity of studies in which teachers' views on the main stakeholders are taken into account. Therefore, more studies of the present nature should be conducted. The theory of Intercultural Language Learning (Liddicoat et al., 2003) emphasises incorporating various cultures in teaching materials for developing Intercultural Communicative Competence in learners. In this context, the Federal Ministry of Education, Pakistan, should provide detailed guidelines for incorporating various cultures in textbooks in the National Curriculum for English Language Grades I-XII. Moreover, the authorities concerned should also monitor whether the specified guidelines are followed in true spirit.

\section{REFERENCES}

Aftab, A. (2011). English language textbooks evaluation in Pakistan. PhD thesis, University of Birmingham, England.

Ahmed, F. \& Narcy-Combes, M. F. (2011). An analysis of textbooks from a cultural point of view. TESOL Journal. 5, 21-37.

Aliakbari, M. (2004). The place of culture in the Iranian ELT textbooks in high school level. The Linguistic Journal. 1, 1-14.

Alptekin, C. (1993). Target-language culture in EFL materials. ELT Journal. 47(2), 136-143.

Ashraf, S. (2008). An analysis of syllabus of English at secondary level. Master's thesis, NUML, Islamabad, Pakistan.

Byram, M. (1993). Language and culture learning: The need for integration. In Byram, M. (Ed.). Germany, its representation in textbooks for teaching German in Great Britain. (pp. 3-16). Frankfurt: Diesterweg.

Byram, M. \& Morgan, C. (1994). Teaching-and-learning language-and culture. Clevedon: Multilingual Matters.

Byram, M. (2011). Intercultural citizenship from an international perspective. Journal of the NUS Teaching Academy. 1(1), 10-20.

Canagarajah, S. (2006). Changing communicative needs, revised assessment objectives: Testing English as an international language. Language Assessment Quarterly. 3(3), 229-242.

Chastain, K. 1988. Developing second language skills. San Diego: Harcourt Brace Jovanovich.

Cobussen, T. (2008). English education in Pakistan. Master's thesis, Utrecht University, Utrecht, Netherlands.

Cortazzi, M. \& Jin, L. (2013). Cultural mirrors: Materials and methods in EFL classroom. In Hinkel, E. (Ed.). Culture in second language teaching. (pp. 196-219). Cambridge: Cambridge University Press.

Council of Europe. (2001). Common European framework of reference for languages: Learning, teaching, assessment. Cambridge: Cambridge University Press.

Dar, S., \& Masroor, F. (2019). Cultural dissemination: A case study of English textbooks at primary level in Pakistan. International Journal of Innovation in Teaching and Learning (IJITL). 5(2), 33-48.

Davcheva, L., \&Sercu, L. (2005). Culture in foreign language teaching materials. In Sercu, L., E. Bandura, P. Castro, L. Davcheva, C. Laskariodou, U. Lundgren, M. Carmen, M. Garcia \& Ryan (Eds). Foreign language teachers and intercultural competence: An international investigation (pp.90-110). Clevedon. Buffalo. Toronto: Multilingual Matters LTD.

Fairclough, N. 2003. Analyzing discourse: Textual analysis for social research. London: Routledge.

Federal Ministry of Education, Pakistan. (2006). National Curriculum for English Language Grades I-XII . Retrieved from http://www.786times.com/ttsskpr/Pakistan-NATIONAL-CURRICULUM-Syllabus-forschools.php

Gay, L. (n.d.). Educational research. Islamabad: National Book Foundation. 
Habib, A. (2014a). An evaluation of English textbooks at SSC level in government schools of Khyber Pukhtoonkhwa. Master's thesis, NUML, Islamabad, Pakistan.

Habib, A. (2014b). An analysis of cultural load in English textbooks taught in Khyber Pakhtunkhwa, Pakistan. NUML Journal of Critical Inquiry. 12(2), 72-88.

Habib, A. \& Saleem, M. (2016). The construction of national and Muslim identities through academic discourse. Tahdhīb al Afkēr. 3(2), 19-28.

Habib, A. (2020). Cultural load in English textbooks at secondary level in the government schools of Pakistan. $\mathrm{PhD}$ thesis, Air University, Islamabad, Pakistan.

Herron, C., Dubreil, S., Cole, S. P. \& Corrie, C. (2000). Using instructional video to teach culture to beginning foreign language students. CALICO Journal. 17(3), 395-427.

Hymes, D. (1972). On Communicative Competence. In J.B. Pride and J. Holmes (Ed.). Sociolinguistics. (pp. 26993).London, England: Oxford University Press.

Iqbal, J. (2013). A review of English textbook at secondary level in the province of Khyber Pakhtunkhwa, Pakistan. Research Journal of Educational Sciences. 1(3), 1-5.

Iriskulova, A. (2012). The investigation of the cultural presence in Spot On 8 ELT textbook published in Turkey: Teachers' and students' expectations versus real cultural load of the textbook. Master's thesis, Middle East Technical University, Turkey.

Jiang, W. (2000). The relationship between culture and language. ELT Journal. 54(4): 328-334.

Kumaravadivelu, B. (2008). Cultural globalisation and language education. New Haven: Yale University Press.

Liddicoat, A.J., Scarino, A., Papademetre, L., \& Kohler, M. (2003). Report on intercultural language learning. Canberra: Commonwealth Department of Education, Science and Training.

Longman Dictionary of Language Teaching and Applied Linguistics (2010). Harlow: Pearson Education Limited. Mahmood, M. A., Asghar, Z. M., \& Hussain, Z. (2012). Cultural representation in ESL textbooks in Pakistan: A Case. Journal of Education and Practice. 3(9), 35-42.

Mohibullah. (2021). A content analysis of the intermediate English textbook-1 taught in government colleges in Khyber Pakhtunkhwa: A study of language skills. Master's thesis, University of Peshawar, Peshawar, Pakistan.

Nault, D. (2006). Going global: Rethinking culture teaching in ELT contexts. Language, Culture and Curriculum. 19(3), 314-328.

Politzer, R. (1959). Developing cultural understanding through foreign language study. In Report of the Fifth Annual Round Table Meeting on Linguistics and Language Teaching. (pp. 99-105). Washington: Georgetown University Press.

Sercu, L. (2005). Teaching foreign languages in an intercultural world. In Sercu, L., Bandura, E., Castro, P., Davcheva, L., Laskariodou, C., Lundgren, U., Garcia, M. D. C. M. \& Ryan. P. (Eds.). Foreign language teachers and intercultural competence: An international investigation. (pp. 90-110). Toronto: Multilingual Matters LTD.

Sharifian, F. (2013). Globalisation and developing metacultural competence in learning English as an International Language. Multilingual Education. 3(7).

Tomalin, B. \& Stempleski, S. (1993). Cultural awareness. Oxford: Oxford UniversityPress.

Umar, H. (2013). Pedagogical practices of English language teachers at the higher secondary level in Pakistan: An evaluative study. PhD thesis, NUML, Islamabad, Pakistan.

Wandel, R. (2003). Teaching India in the EFL-classroom: A cultural or an intercultural approach? In Byram, M. \& Grundy, P. (Eds.). Context and culture in language teaching and learning. (pp. 72-80). NY: Multilingual Matters.

Yaqoob, M. T. (2011). Ideology and worldview in textbooks: A study of cultural aspects in ELT in Pakistan. PhD thesis, Bahauddin Zakariya University Multan, Pakistan. 